\title{
Impact of Intellectual Property Rights Institutional Quality and Financial Development on Foreign Direct Investment - Evidence from Developing Coun- tries
}

\author{
Palwasha Farooq*1, Arshad Hassan², \& Junaid Ahmed ${ }^{3}$ \\ ${ }^{1,2}$ Capital University of Science and Technology, Islamabad, Pakistan \\ ${ }^{3}$ Pakistan Institute of Development Economics, Islamabad, Pakistan
}

\begin{abstract}
The current study explores the impact of intellectual property right, financial development and institutional quality on foreign direct investment. Data of patent index were used as a proxy of intellectual property right. Financial development index and institutional quality variables were taken from ICRG for the period of 1980-2016, by applying pooled OLS, fixed test. Sample of 123 developing countries data set were used. The results are consistent with theory of OLI presented by Dunning 1979. The results explain more than 70 percent of FDI significance level is explained by these proxies. The only paper that identifies Patent right index is by Park (2008) that took patent index from 1960-2005. Furthermore, work is under taken where the patent right variables are taken as independent variables. On the contrary previous studies have empirically examined the effect of patent proxy effect on the creativity, innovations and the dissemination of the technology transfer. This study differs because patent index is included with institutional quality variables. Beside this the high level financial development is a catalyst in attracting FDI. Moreover, the FDI is higher in military regime, which is due to higher level of dis stability regime in the country. However, results shows that developing countries can improve regulatory quality by maintaining bureaucracy and accountability to enable them to take advantage from the external finance which further boosts the growth of economy.
\end{abstract}

\section{Introduction}

One of the principal factors that encourage FDI inflow is an improvement in the government institutions and business climate (Adams, 2008). Strengthening of IPR reforms through financial development and institutional quality is a cause of FDI inflow (Stanley et al., 1996). There exists an increase in high quality of FDI due to increased level of IPR protection (Glass, 1997). During the decade of 1980 and 1990s FDI attracted the attention of scholars due to financial liberalization globally. Moreover, as far as theoretical perspective is concerned as suggested by Fischer (2001), that immense rate of social welfare and enhanced economic efficacy is due to the liberalization of capital account (Singh, 2003). The foremost impact on FDI inflow is through the phenomena of good governance, which is identified through tangled system of process having characteristics of accountability and transparency and effectiveness of legal system and financial liberalization (Santiso, 2001). However global FDI trends hold less momentum in 2016 .But the global FDI flows mostly decline by 3 percent to approximately 1.43 trillion dollars in the year of 2017 (UNCTAD,2018). FDI inflow

*Corresponding author.

Email: palwashafarooq24@gmail.com and its recorded value to the developing countries is the largest source of the foreign financing as compared to other portfolios investments. (World investment Report 2018). Thus, in essence the presence of the specific formal institutions are ensured and found to exert influence on the foreign direct investment .For instance, presence of private ownership of the business sector, banking sector reforms and the foreign exchange along with trade liberalization and also the developmental phenomena (Bevan et al., 2004).

It is important to identify the appropriate determinants of FDI so that the suitable policies can be devised in order to enhance the output of the FDI. However, with the exception of a few studies that emphasized on FDI from Asian and European countries, the existing empirics along with literature have mainly focused on the suitable determinants of the FDI by employing firm level approach and country level approach. The literature elucidates the different macroeconomic variables and key determinants of FDI that were taken into account to analyze such as the trade openness, the telephone lines, the GDP per capita and the size of economy (Bevan et al., 2004; Moosa and Cardak, 2006). At the macroeconomic level, Buchanan et al. (2012) found 
that the institution quality has an impact on the FDI has almost positive and significant results, whereas by a rise in change of one standard deviation, institutional quality and FDI increase by a factor of 1.69. On the other hand, at the micro economics level, Kinda (2010) found that there is high co relation in the institutional quality and the firm level resources. Furthermore, the tests that are significant for three European counties indicate there exists a positive significant relation between regional interaction and firm level resources. While, Strine Jr (2010) found supporting evidence for the measures of the institutional quality mostly emphasizing on governance and their immediate impact on Foreign direct investment; along with the composite linkage, their return is greater in the developing transition countries as compared to the other countries. Gani (2007) concluded that rule of law ,regularity quality, political instability and governance is correlated to FDI in a sample countries of Asia ,Latin America and the Caribbean region. Busse and Hefeker (2007) found Political risk components include important determinants like corruption, bureaucracy and rule of law which have significance relation towards the determinants of foreign direct investment (Kaufmann and Wei, 1999).

There are two contrasting views of how the mechanism of strengthening of protection of intellectual property right enhances the encouragement of FDI inflows. Thus its believed that there exists a positive relationship between intellectual property right and FDI inflows and how its being affected by financial development and soundness of economy, along with the institutional quality. As its widely known and acknowledged that the TRIPS Agreement is the most vital and important instrument which plays a crucial role concerning Intellectual Property protection. Thus plays a prominent role in the promotion of the technological innovation and also to the transfer and dissemination of the technology needs. It is a great argument that how the developed countries with the strengthening patent protection will enhance the foreign direct investment in the context of developing countries and this will ultimately lead to an increased level and also greater transference along with usage of technology thus, promulgating how the TRIPS Agreement meets its objectives in regard to scenarios of country. On the other hand, not all scholars support the view that IPR is robust to enhance the FDI. There are certain argument pertaining to that IPR protection is negatively associated with economic growth which in turn effect the FDI and discourages new entrants from entering into technology entrepreneurship sector. The likelihood that how firms align their path to access and efficiently absorb technological diffusion that is most probably either through informal or formal channels most depend on the prevailing circumstances and characteristics of operating countries in which they are located, along with capacities orientation and nature of technologies used are still in question. It is quite obvious that, the size of economy and expected growth of the markets of the economy ultimately act as an incentive for FDI and inward licensing most prominently Maskus et al. (2005); Xavier-Oliveira et al. (2015). Thus the monopolistic nature of IPR and its profound impact on IPR varies and infer the emerging need to devise optimal IPR protection policies that will prove vital in the enhancement of FDI inflow. Thus it is concluded that the Foreign Direct Investment (FDI) is a basic necessity in the developing economics simply because most of the included countries do not have the capital allocation to fund the most expensive innovations and creativity on their own. FDI has become accrue liability to the developing countries. Thus in order to promote creativity and the technological innovation, it is obvious and clear by the promulgation of the substantive provisions of the TRIPS Agreement (Smarzynska Javorcik, 2004). As it is conferred that challenges pertaining to the policy makers mechanism can robustly influence the economic performance. It is crucial to illustrate to relating the developmental stages pertaining to effective decision making, while investing in a foreign markets that usually illustrated the dynamic fluctuating scenario of the diverse markets. As stated that the results of this inherent lacuna that how MNEs adapt to environmental factors to make appropriate behavioral decision making that is inconclusive to best guidance for policy implications does not allow best model in international markets (Aharoni, 2010). Developing nations typically have low resources and less revenue. They need to fill gap of fiscal deficit, so they borrow from external resources .Utilization of external funds depends upon the efficiency of administration .Good administration empowers a nation to accomplish its growth objectives and get to be distinctly prosperous, by setting up a conducive domain for the high and supportive financial development (North, 1997).

To the best, there exists a scarcity of literature that paid attention to small data set apart from the literature. The current study inspects set of macro-economic variables and institutional variables for 123 countries for the era of (1980-2016) the furthermost comprehensive records of data sample to date of the country studies of the large date of the country set.

The behaviour of the multinational behaviour is investigated by the interaction of industry characteristics versus intellectual property rights (IPRs). The results show how the firms in the industrial sector with high capital costs and the budgeting techniques are more likely to maintain the steady controlling mechanism over the productive knowledge, in countries with the low level of the intellectual property protection, by ensuring that the foreign direct investment (FDI) must increase. Moreover, when IPRs are optimal, and the firms in industry sector with high level of the investment in research and development (R\&D) are more likely to en- 
ter a specific market by the licensing to an unaffiliated and specific host firm (Fellner and Maciejovsky, 2007). Since the end of the 80s intellectual property right protection (IPRs)has become the most vast and the prominent issue that depicts how the strategies of countries ,especially in terms of foreign direct investment (FDI) should influence the country reserve. Later during the year of the 1994 to 1995, the introduction of TRIPs in the GATT and onwards the WTO pushed this known TRIPS worldwide. This also depicts that the IPRs protection goes to a high tide. Most obviously such a campaign on IPRs protection have reflective impact on the following two attributes of the present market competition, and ensuring the greater impact on the IPR policy on foreign direct investment. Due to this sort of global pressure, should results on the strengthening IPRs protection in developing countries has should become an unavoidable tendency in the order to get increased level of foreign direct investment, This probably results in the access of the better technologies and ultimately to attain high growth level (Puerta-Gomez and Cisneros-Zevallos, 2011).

The only paper that identifies Patent right index is by Park and Ginarte (1997) that takes patent index from 1960-2005. Furthermore, work has been undertaken where the patent right variable has been taken as independent variables. Most probably the previous studies have empirically examined the effect of patent proxy effect on the creativity, innovations and the dissemination of the technology transfer. This study differs because patent index is included with institutional quality variables. An Exhaustive literature inspected a lot of studies on the foreign direct investment and impact of the patent on the innovation and technology transfer. Despite the increase of flows, to date, very little attention has been gathered towards the macroeconomic variables and the quality of the institutional variables that ultimately affect FDI. Moreover Patent, index based on 5 years intervals from 1960-2010 has been used. More specifically, we answer the following question:

- Is Patent index a good proxy of the intellectual property right?

- What is relationship of institutional quality with foreign direct investment?

- Is financial development index drive flow of the foreign direct investment?

The study attempts this question using data set for a period of 1980-2016 consisting of 123 developing countries based on income groups. To answer the first question, we estimated the patent index of patent right protection into the model as a proxy, instead of intellectual property right. In order to answer the second question we constructed institutional quality variable, i.e. Bureaucracy, rule of law corruption have been taken from political risk component and its impact on FDI. The third question is about financial development proxies. That is third index of financial development, i.e. the index of the financial market; financial institution and the financial development are used as a three proxy towards the influence foreign direct investment. There exist many theories which explain the importance of FDI such as imperfect market theories, industrial organizational theory internationalism theory (Jahn, 2009; Naik et al., 2018; Pichler and Wilhelm, 2001). With regard to above theories this study is based on OLI theory proposed by Dunning 1980. Very few researchers have attempted to study the relationship between inflow of foreign direct investment and OLI paradigm independently, for the developing economics. However, the study considers this important theory as a base, because it is related to foreign direct investment. Dunning OLI paradigm for evaluating the significance and relationship from the relationship, aim to formulate effective policy concern.

\section{Literature Review}

FDI is a known topic in the contemporary literature that has mainly focused on the importance and prominence of IPR, institution quality \& the financial development. The effects of these factors so far have not been investigated in the context of the developing economies. Empirically the alliances between IPR and the quality of the institutions and the development of the financial indexes on the foreign direct investment are diverse in nature. Dunning and Zhang (2008) theorized that FDI could be attracted in the firm by increasing the investment strategies. Thus it can increase the ownership advantages, getting beneficial from the internalization associated with the advantages, ensuring the maximum output of the advantages via ownership .He also narrated that the total FDI benefits should need to overshadow related costs that is incurred for setup and initiate the locations. If not, in contrast to set up a foreign locations, thus industry would be better off, contended to export the particular products. There is some proof to the support to the idea that FDI should enhance the competitiveness of the local industry sector, thus gaining core competency.

\subsection{Intellectual Property Right and FDI}

Smarzynska Javorcik (2004) discussed those government agencies that do facilitate in order to attract the FDI with the hope that multinational corporations will subsequently bring new technology and skills. Moreover, IPR protection affects FDI by particular sectors, especially in the case of transitions economies. She debates that weaker IPR protections discourages and deters in both the non-sensitive and sensitive fac- 
tors. This could possibly be implemented when it undertakes local production and forces them into distribution industries. Moreover, in order to inspect the spillover effects of FDI on creativity and innovativeness in China, a technique named as regression is used to examine for the cross-section and data pooled time-series (OLS) technique is used as well, by pooling together both cross-section and time series data. However, to examine the regional heterogeneity across provinces, Panel data analysis is taken into account. These findings represent very little evidence associated with the spill over impact on FDI in China. There exists a more satisfactory and convenient approach to utilize observations from smaller spatial units from such counties whether FDI and innovativeness with country level data in the country China are available, with keeping in mind the future direction pertaining to the crowding effect (Cheung and Ping, 2004).

Schneider (2005) demeanor investigation that is empirical in nature highlighted the main role of trade in order to fix the socio economic variables in transition countries and rate of innovation. Also showing how the impact of importance of both FDI and IPRs occur in these processes. However, a sample of 28 developing countries and 19 developed countries are used. WDI is the main source of extracting data variables. Thus, it was concluded that FDI has been acknowledged in the literature as one of the most important and vast channels for the purpose of technological diffusion. There has been the link between technological diffusion and trade in physical goods. Gervais (2005) formulated a strategy for the intellectual property right and how it possibly reveals some of the major suggestions .Because IP could be better modified to best fit the needs and wants of the developing economies. However, it also highlights the major economic play that is known as deciding analytical tools.

A strong agreement on the topic of the strengthening and protection of IPR among economists is growing nowadays, that shows how patent protection affects and harmonizes the economy. Grossman and Lai (2004) inspected the major incentives that are needed by the government and agency utilize in order to protect the Intellectual property right in a world trade economy and competitive era. The study explores the relation of world economy with more on going innovativeness. Moreover its formulated that national patent policies determination in a regime of non-cooperative sector of the patent protection, it also reveals international patent agreements from efficient global regime of the patent protection, it can be done via deriving the properties in a global sector. Furthermore, the implications of the policies are discussed along with focusing global efficiency along with patent harmonization. Iwaisako (2018) described how the protection of the patent effects on the country welfare state. It also enhances facilitating the foreign direct investment strate- gies via constructing a model of North-South qualityladder in which endogenous location choice of firms is determined by foreign direct investment (FDI). Park and Ginarte (1997) demonstrates an update included in the index of the protection of patent published in the journal in the year of 1997 . However the paper reports the index for the year of 1960-1990 for the period of 110 countries. In addition the index has also been updated to the year of 2005 and moreover for the period of 122 countries. The stronger patent laws adoption and patent right composition almost vary across the countries by ensuring the level of economic development. Evan et al (2018) studies how to theoretically derive and thus ensuring the effects of the intellectual property right on term of national economics.

\subsection{Financial Development and FDI}

Financial system and its development role in enhancing foreign direct investment along with economic growth is done through depicting the major key towards the technological diffusion process, which is associated with FDI. Moreover there is a growing interest by economists towards financial development and the foreign direct investment. Hermes and Lensink (2003) investigated importance of domestic financial system and foreign direct investment role and also illustrated that financial system does increase more efficient allocation of the total resources and in this way its helpful in improving the absorptive capacities of the country in regard to inflow to FDI. Similarly, study by Agbloyor et al. (2013) illustrates the long horizon perspective by forming the linkages the FDI and financial market development mechanisms. The sample data is based on sub-Saharan African region of eight countries in total for the year of 1991-2013. Subsequently, the results coherent to causality test and 2SLS panel regression depict that two variables relation, i.e. financial market development and FDI is found to be inclusive. Another study of Hermes and Lensink (2003), states that the financial system development of the recipient country is one of the important condition for the FDI that exert positive influence via economic growth. However the process of technological diffusion is facilitating by more developed financial system.

\subsection{Institutional Quality and FDI}

There exists diverse relationship between FDI and institutional quality. Accordingly Cuervo-Cazurra (2006) focused on the relation and the impact of corruption on foreign direct investment (FDI).Furthermore ,debates how the corruption will result not only in slower impact in FDI inflows, but also shows that composition of the country and its changing result in origin of the FDI It also reports two major findings; firstly, how the value of the corruption will be lower than 
FDI. Furthermore, the corruption will be lower from those countries that signed Convention on Combating Bribery of Foreign Public Officials in International Business Transactions. This is further suggested that in case of the corruption in the foreign countries, there should be formulated laws against bribery abroad .Secondly the corruption also results in higher level of corruption in engaging in foreign countruies.This proposes that the investors should be exposed to the bribery at home place should not invest abroad, thus in place reach to those countries where corruption is prevailing.

Bénassy-Quéré et al. (2007) examined role of institution in the host \& source country analysis using bilateral stock by estimating gravity by tackling multicollinearity \& endogenisis bias. It also focuses on institutional distance effects on the bilateral FDI by accessing frasher data coverage of industrial and developing countries. Increase in inward FDI has been observed by focusing on bureaucracy, corruption and legal institutions. Hence the weaker and lesser capital concentration and the protection of employment slow the inward FDI. Its concluded impact of institutional quality on bilateral FDI.

Busse and Hefeker (2007) explores the data linkages formation that exists between the institutions, the political risk of the institutions and foreign direct investment. Overall, political risk and institution quality including the 12 different sorts of indicators are used in the empirical analysis. However, the results indicate that the absence of internal conflict, ethnic tensions, government stability, and the basic democratic rights via law order are highly related to the determinants of foreign direct investment inflows.

\subsection{Macroeconomic Variables and FDI}

Adams (2008) explained the importance of the IPR and its strengthening impact along with discussing positive effect on FDI. Besides it has also been discussed how the macro economic variables play a crucial role in order to increase the FDI inflows. This basic assumption underlying those investments done in the countries that have a lower per capita income result in yielding a higher rate of return. The variables which are obtained from the Political Risk Services Country Risk Guide include the risk variable (RISK), which is a composite measuring of the investment climate. It basically is composed of three sort of measures: financial, political, and the economic risk.

Henriques et al. (2010) used a project level unique rich data set, which is used to analyze the trends and determinants of the FDI inflows to the region of the Southern African Development Community (SADC). Beside this controlling the sources of the investment is undertaken and with the type of investment to the project size addition. The results are coherent to the market size that is to have a positive significant impact on FDI inflows that is included in under all specifications, thus a result is consistent with the earlier studies.

\section{Research Methodology}

The study aims at exploring the relationship among intellectual property right, institutional quality and financial development. Annual panel data from 19802016 are used for analysis. The sample consisting of 123 developing countries is divided into the two income level.The data gathered from various sources such as World Bank database (World development indicators, international financial statistics and Walter park index. Such as LGDP is the log GDP measure of the size of the economy, LLF is labor force ,INF is the inflation ,TOP is the trade openness, MPS is the mobile per subscription 100 people, GDPC is the GDP per capita, extracted from WDI .FINDEX is the proxy for financial development and it is composed of three index of financial development, which are taken from IFS,INSQ composed of four quality measures including corruption, bureaucracy Military ,rule of law, are taken from ICRG. Patenta is the measure of used as a proxy of intellectual property right, data taken form Walter park index.

\subsection{Panel Data Estimation}

Panel data is a combination of time series and cross sectional data. Panel dataset on individuals and households are difficult to obtain as compared to pooled cross section this is mainly because it requires replications of same units over times .Multiple observations on the same units allow to include unobserved characteristics of individuals; firms, etc. (Wooldridge, 2015). The pooled model assumes that unobservable characteristics are constant, independent of heterogeneity. In this context, OLS produces consistent estimator thus, we refer to pooled OLS estimation. If the assumption regarding the unobservable variables is wrong, we are in the presence of an omitted variable. Then, we have potential bias and inconsistency of pooled OLS. The magnitude of these problems depends on how the true model behaves: fixed or random. In the pooled model, there is no model for group/individual heterogeneity. Thus, pooled regression may result in heterogeneity bias:

\section{Results}

\subsection{Descriptive Statistics}

Table 1 shows descriptive statistics, which represent statistical attributes of all variables for developing countries during period of 1981-2016 including mean, median, maximum and minimum values along with 
Table 1: Descriptive Statistics

\begin{tabular}{lccccc}
\hline Variable & Units & Mean & Std. Dev. & Min & Max \\
\hline FDI inflow & US dollar & 5.406502 & 2.365715 & -2.30259 & 12.58083 \\
Lgdpc & $\%$ & 9.386267 & 2.01213 & 3.602777 & 16.23135 \\
Llf & - & 1.438173 & 1.711297 & -2.30259 & 6.668355 \\
Inf & $\%$ & 14.85097 & 35.65991 & -23.8 & 492.4 \\
Tradeopness & $\%$ & 78.4781 & 41.47297 & 0.2 & 531.7 \\
Mobile & $\%$ & 47.02152 & 47.8378 & 0.1 & 223 \\
Gdpg & $\%$ & 3.796967 & 7.619003 & -62.1 & 179.2 \\
Fdind & - & 0.182386 & 0.118517 & 0.002477 & 0.823458 \\
Fmi & - & 0.095954 & 0.148238 & $2.38 \mathrm{E}-11$ & 0.876004 \\
Fiindex & - & 0.272438 & 0.130708 & 0.022924 & 0.798114 \\
Patenta & - & 2.072097 & 0.8564 & 0.13 & 4.33 \\
Corruption & - & 2.663292 & 1.01807 & 0 & 6 \\
Law & - & 3.472803 & 1.457224 & 0 & 6 \\
\hline
\end{tabular}

standard deviation of all the variables The FDI mean value is 5.4 , least value is -2.30 and extreme value is 12.58 while volatility is 2.36 . Log GDP per capita/size of economy has mean value 9.36 , minimum value is 3.6677 and maximum value is 10.231 and standard deviation is -201213 . The mean value of labor force is 1.43 where minimum value is about -2.30 and maximum value is 6.668 and volatility is 1.711 . The mean value of inflation is 35.6591 and minimum value of 23.8 and maximum value is 492.4 . Trade openness has a standard deviation of 41.4729 and minimum value is 0.2 and max value is 531.17.Mobile phone has mean value of 47.021 where standard deviation is 47.8378 , and minimum value is 0.1 and maximum value is 223 . GDP growth rate has a standard deviation of 7.6190 and the maximum value is 179.2 and minimum value is -6.21 .

Financial development has three proxies, financial development index has a mean value of 0.1823 it has a standard deviation of 0.1185 whereas it has a minimum value of 0.0025 and maximum value of 0.825 . Financial market index has standard deviation of around 0.148 and the minimum value is 2.38 and maximum value is 0.876004 . Financial institution index has variability of 0.130708 and the minimum value is 0.222924 and maximum value is 0.798114 .Institutional quality is measured by four proxy i.e. corruption, Rule of law, Bureaucracy, Military. Corruption is the measure of the institutional quality it has maximum value of 6 and the minimum value is 0 . Bureaucracy has a standard deviation of 1.0807.Rule of law is the second proxy of the measure of institutional quality.it has a maximum value of 6 and minimum value is 0 , whereas, it has a standard deviation of 1.457224 Bureaucracy is the third proxy of the measure of institutional quality it is taken also taken from ICRG by political risk component $\mathrm{Bu}-$ reaucracy has variability of 1.094076 and has maximum value of 4 and minimum value of 0 . Military is the fourth proxy of the measure of institutional quality. It is taken also taken from ICRG by political risk component. Military has 1.595 of standard deviation and has an extreme value of 6 and minimum value of 0 .Intellectual property right is measured by proxy of patent and it is taken from Walter Park index. Patent has standard deviation of 0.8564 , and has an extreme worth of 4.33 and the least worth of 0.1 .

\subsection{Correlation Matrix}

Table 2 represents correlation matrix. Size of economy is found significantly and positively related to labor force, trade openness and mobile phone as above. Moreover GDP per capita is positively correlated with size of economy, Trade openness, labor force. As shown above, the macro-economic variables, the left variables such as inflation insignificant relationship is observed Financial development is measured by three proxies such as financial institution index, financial development index and financial market index. A significant correlation is observed Institutional quality is measured by four proxies such corruption, military, bureaucracy, rule of law, there exist a positive significant relationship. Moreover in patent is a proxy to measure intellectual is highly correlated.

\subsection{Pooled OLS and Hausman Test}

Table 3 reports the grades of panel design analysis performed to explain the impact of macro-economic variables on FDI .This includes size of economy, inflation, trade openness, labor force and mobile phone on foreign direct investment. The results indicate that as size of economy increases, it attracts more FDI. The larger economies have more FDI as compared to smaller economies. The labor force has insignificant and positive impact on FDI. The positive sign indicates that more FDI due to availability of cheap worker. As 
Table 2: Correlation Matrix

\begin{tabular}{|c|c|c|c|c|c|c|c|c|c|c|c|c|c|c|}
\hline variable & Lgdpc & Llf & inf & Top & Mobile & gdpg & fdind & fmi & fiindex & patenta & corrup & law & bur & milt \\
\hline lgdpc & 1.000 & & & & & & & & & & & & & \\
\hline llf & 0.813 & 1.000 & & & & & & & & & & & & \\
\hline $\inf$ & -0.130 & -0.032 & 1.000 & & & & & & & & & & & \\
\hline tradeopness & -0.536 & -0.592 & 0.338 & 1.000 & & & & & & & & & & \\
\hline mobile & 0.227 & -0.122 & -0.186 & 0.138 & 1.000 & & & & & & & & & \\
\hline gdpg & 0.119 & 0.177 & -0.060 & 0.069 & -0.06 & 1.000 & & & & & & & & \\
\hline fdind & 0.681 & 0.460 & -0.126 & -0.105 & 0.339 & 0.044 & 1.000 & & & & & & & \\
\hline fmi & 0.702 & 0.627 & -0.084 & -0.181 & 0.147 & 0.127 & 0.899 & 1.000 & & & & & & \\
\hline fiindex & 0.454 & 0.115 & -0.142 & 0.023 & 0.481 & -0.073 & 0.834 & 0.507 & 1.000 & & & & & \\
\hline patenta & 0.099 & -0.102 & -0.253 & 0.044 & 0.529 & -0.113 & 0.264 & 0.083 & 0.413 & 1.000 & & & & \\
\hline corruption & -0.054 & 0.008 & 0.131 & -0.028 & -0.08 & 0.093 & 0.013 & 0.002 & 0.022 & -0.015 & 1.000 & & & \\
\hline law & -0.331 & -0.322 & -0.077 & 0.177 & -0.02 & -0.066 & -0.198 & -0.217 & -0.115 & 0.003 & 0.085 & 1.000 & & \\
\hline bur & -0.183 & -0.233 & -0.088 & 0.197 & 0.184 & -0.223 & 0.087 & 0.026 & 0.138 & 0.330 & -0.186 & -0.102 & 1.000 & \\
\hline milt & 0.052 & -0.112 & -0.105 & 0.011 & 0.212 & 0.006 & 0.309 & 0.210 & 0.343 & 0.220 & 0.245 & 0.228 & 0.025 & 1.000 \\
\hline
\end{tabular}

indicated in Haussmann relationship is significant so fixed effect model is appropriate Inflation is interpreted as insignificant the significant intercept is indicator of performing well. The trade openness has significant impact on foreign direct investment. The countries with more international trade relationship attract more foreign direct investment. The use of mobile is an indicator of technology using by masses of a country. The results further indicate that high level of technology leads to more FDI as this explains significant relationship between mobile phone subscription and FDI. High economic growth role in a well-established is an indicator of FDI. The same confirmed as there exists a significant relationship between economic growth and FDI. The higher growth attracts higher FDI. The intercept is significant that indicates the possibility of missing variables. Such variables are explained in next phase of study. Some of variables are financial development .institutional quality, and the intellectual property. Moreover the explanatory power of model is $74.1 \%$ which is reasonably good.

\subsection{Financial Development and FDI}

Table 4 represents the influence on financial development on foreign direct speculation. Three different proxies of financial development are used including index of financial development index of financial market and index of financial institution. The results indicate that all proxies of financial development have significant positive relationship with FDI. The high level financial development is a catalyst in attracting FDI, so far as results are concerned. In model, financial market index is used as a substitution of monetary development. Sound and well established market enhances more financial development. This would ultimately in- crease more FDI inflow .Financial market index is significant size of economy has significant partial relationship with FDI. This means big economies will attract more FDI. Similarly Labor force and FDI have significant relationship with FDI.The countries that have cheap labor manpower will attract more FDI. Trade openness has important relationship with FDI There exists an optimistic relation among financial market index and trade openness. More attractive relationships attract more external finance thus enhance financial market development. This means more open trade policies will attract more foreign direct investment. It is further added that insignificant relationship is observed between inflation growth per capita and FDI. An intercept is significant, indicating the possibility of missing variable. Some of them are explained in next section. The explanatory power of the model is $71 \%$ which is reasonably good.

In model financial institution index is used as a proxy of economic growth .Sound and well quality of financial institution enhances more financial development. This would enhance more FDI inflow. Financial institution is significant, whereas, size of economy has a significant relationship with FDI. This means big economies that are financially sound will attract more FDI. Labor force has a significant relationship with FDI. The countries that have cheap labor manpower will attract more FDI. Trade-openness has significant relationship with FDI. It is observed that there exist an optimistic relationship among trade openness and financial institution index because trade openness promotes increase in financial institution index. A good institution enables the financial institution channels to work in a productive manner thus reducing waste and enhancing quality of institutions, which results in financial devel- 
Table 3: Pooled OLS and Hausman Test

\begin{tabular}{lccc}
\hline & $\mathbf{( 1 )}$ & $\mathbf{( 2 )}$ & $\mathbf{( 3 )}$ \\
\hline VARIABLES & Pooled Effect & Fixed Effect & Random Effect \\
\hline Size of economy & $0.816^{* * *}$ & $0.845^{* * *}$ & $0.816^{* * *}$ \\
& $(0.0301)$ & $(0.0307)$ & $(0.0329)$ \\
Labor Force & $0.0666^{* *}$ & 0.0402 & $0.0666^{*}$ \\
& $(0.0303)$ & $(0.0363)$ & $(0.0385)$ \\
Inflation & -0.00137 & -0.000933 & -0.00137 \\
& $(0.00148)$ & $(0.00130)$ & $(0.00122)$ \\
Tradeopness & $0.00681^{* * *}$ & $0.00684^{* * *}$ & $0.00681^{* * *}$ \\
& $(0.000612)$ & $(0.000515)$ & $(0.000504)$ \\
Mobile per 100 people & $0.00539^{* * *}$ & $0.00253^{* * *}$ & $0.00539^{* * *}$ \\
& $(0.000601)$ & $(0.000847)$ & $(0.000715)$ \\
GDP per capita growth & $0.0222^{* *}$ & $0.0198^{* *}$ & $0.0222^{* * *}$ \\
& $(0.0112)$ & $(0.00941)$ & $(0.0102)$ \\
Constant & $-2.678^{* * *}$ & $-2.787^{* * *}$ & $-2.678^{* * *}$ \\
& $(0.263)$ & $(0.252)$ & $(0.262)$ \\
Observations & 1,802 & 1,802 & 1,802 \\
R-squared & 0.741 & 0.716 & \\
Number of year & & 27 & 27 \\
Country FE & & YES & \\
Year FE & & YES & \\
Hausman test & & Prob >chi2 & \\
& & $=0.0119$ & \\
\hline Rob & & &
\end{tabular}

Robust standard errors in parentheses

${ }^{* * *} p<0.01,{ }^{* *} p<0.05,{ }^{*} p<0.1$

opment This means more open trade policies will attract more foreign direct investment .Inflation is also partial significant with FDI.Low level of inflation will influence FDI.Mobile phone per 100 peoples is significant as there exist more technology usage by masses there is more institution quality financially. It is further added that insignificant relationship is observed between growth per capita and FDI An intercept is significant ,indicating the possibility of missing variable Some of the which are explained in next section. The explanatory power of the model is $73 \%$ which is reasonably good.

\subsection{Institutional Quality and FDI}

Table 5 reports patenta is the proxy to measure the intellectual property right it means protection of IPR and its strengthening process will ultimately harmonize the economy In model, corruption is insignificant whereas the size of the economy has significant impact with FDI. This means big economies will attract more FDI. Trade-openness has significant relationship with FDI. This means more open trade policies will appeal additional foreign direct venture FDI. Inflation is partially significant, so low level of inflation will influence FDI.Mobile phone per 100 peoples is significant as there exists more technology usage by masses there is more institution quality financially It is further added that insignificant relationship is observed between inflation, GDPG and FDI Sound and well developed financially institution enhance more financial development. This would enhance more FDI inflow. Financial development index is significant an intercept is significant, indicating the possibility of missing variable. Some of the are explained in next section. The explanatory power of the model is $66 \%$ which is reasonably good.

Strong rule of law and its breach and infringement policies will affect foreign direct investment. Rule of law is insignificant, low level of law and more adjusting policies instead of strong rigid policies will attract more foreign straight stockholders. In Model the size of the economy has significant impact with FDI. This means big economies will attract more FDI. Tradeopeness has significant relationship with FDI. This means more open trade policies will attract more foreign direct investment (FDI) Inflation is partially significant, so low level of inflation will influence FDI. Mobile phone per 100 peoples is significant as there exists more technology usage by masses. There is more institution quality financially, it is further added that insignificant relationship is observed between inflation, GDPG 
Table 4: Financial Development and FDI

\begin{tabular}{lccc}
\hline & $\mathbf{( 1 )}$ & $\mathbf{( 2 )}$ & $\mathbf{( 3 )}$ \\
\hline VARIABLES & Fin Market Index & Fin Inst Index & Fin Deve Index \\
\hline lgdpc & $0.721^{* * *}$ & $0.690^{* * * *}$ & $0.677^{* * *}$ \\
& $(0.0395)$ & $(0.0383)$ & $(0.0399)$ \\
llf & $0.0913^{* *}$ & $0.150^{* * *}$ & $0.115^{* * *}$ \\
inf & $(0.0415)$ & $(0.0388)$ & $(0.0386)$ \\
& 0.000955 & $0.00144^{*}$ & $0.00137^{*}$ \\
tradeopness & $(0.000841)$ & $(0.000813)$ & $(0.000784)$ \\
& $0.00562^{* * *}$ & $0.00577^{* * * *}$ & $0.00543^{* * *}$ \\
mobile & $(0.000672)$ & $(0.000715)$ & $(0.000700)$ \\
& $0.00600^{* * *}$ & $0.00433^{* * *}$ & $0.00485^{* * *}$ \\
gdpg & $(0.00110)$ & $(0.00122)$ & $(0.00124)$ \\
fmi & 0.0157 & 0.0168 & 0.0159 \\
fiindex & $(0.0117)$ & $(0.0119)$ & $(0.0115)$ \\
fdind & $0.918^{* * *}$ & & \\
& $(0.278)$ & & \\
Constant & & $1.429^{* * *}$ & \\
& & $(0.171)$ & \\
Observations & & & $1.625^{* * *}$ \\
R-squared & 1,032 & & $(0.225)$ \\
Number of year & 0.713 & $-1.798^{* * *}$ & $-1.520^{* * *}$ \\
Country FE & 25 & $(0.331)$ & $(0.351)$ \\
Year FE & YES & 1,058 & 1,058 \\
\hline
\end{tabular}

Robust standard errors in parentheses

${ }^{* * *} p<0.01,{ }^{* *} p<0.05,{ }^{*} p<0.1$

and FDI Sound and well developed financial institution enhance more financial development. In contrast low level of law result to some of extent strengthening of patent this means patent are affected and they are not $100 \%$ significant. A low level of significance is observed. This would enhance more FDI inflow. Financial development index is significant an intercept is significant, indicating the possibility of missing variable. Some of which are explained in next section. The explanatory power of the model is $64 \%$ which is reasonably good.

Strong Bureaucratic rule of law will lower the foreign direct investment. As investors are less likely to be concerned to such countries where there are stringent policies. Investors are more likely where there is adjusting and flexible law. This also impacts the labor force In Model the size of the economy has significant impact with FDI. This means big economies will attract more FDI. Trade-openness has significant relationship with FDI. This means more open trade policies will attract more foreign direct investment. Mobile phone per 100 people is significant as there exists more technology usage by masses there is more institution quality financially It is further added that insignificant relationship is observed between inflation labor force ,GDPG,Patents and FDI Financial development index is significant. Well set financial institutions will enhance FDI an intercept is significant, indicating the possibility of missing variable. Some of them are explained in next section the explanatory power of the model is $65 \%$ which is reasonably good.

Military safeguarded the country, this will attract the foreign investors because better policies and check and balance is observed, this will lead to accountability, thus ensures more FDI. In Model the size of the economy has significant impact with FDI. This means big economies will attract more FDI. Tradeopeness has significant relationship with FDI. This means more open trade policies will attract more foreign direct investment. Mobile phone per 100 people is significant as there exists more technology usage by masses there is more institution quality financially An intercept is significant, indicated the possibility of missing variable .Some of the which are explained in next section the 
Table 5: Institutional Quality and FDI

\begin{tabular}{|c|c|c|c|c|c|}
\hline & (1) & (2) & (3) & (4) & (5) \\
\hline VARIABLES & Patent & Corruption & Rule of Law & Bureaucracy & Military \\
\hline \multirow[t]{2}{*}{$\operatorname{lgdpc}$} & $0.604^{* * *}$ & $0.677^{* * * *}$ & $0.681^{* * *}$ & $0.665^{* * *}$ & $0.705^{* * *}$ \\
\hline & $(0.0506)$ & $(0.0587)$ & $(0.0441)$ & $(0.0486)$ & $(0.0494)$ \\
\hline \multirow[t]{2}{*}{ llf } & $0.112^{* *}$ & 0.0271 & 0.0437 & 0.0303 & 0.0556 \\
\hline & $(0.0508)$ & $(0.0540)$ & $(0.0449)$ & $(0.0450)$ & $(0.0431)$ \\
\hline \multirow[t]{2}{*}{$\inf$} & $0.00425^{* *}$ & $0.00759^{* * *}$ & $0.00394^{* *}$ & 0.00264 & $0.00409^{* *}$ \\
\hline & $(0.00160)$ & $(0.00186)$ & $(0.00155)$ & $(0.00191)$ & $(0.00175)$ \\
\hline \multirow[t]{2}{*}{ tradeopness } & $0.00450^{* *}$ & $0.00400^{*}$ & $0.00688^{* * *}$ & $0.00716^{* * *}$ & $0.00671^{* * *}$ \\
\hline & $(0.00167)$ & $(0.00221)$ & $(0.00129)$ & $(0.00140)$ & $(0.00122)$ \\
\hline \multirow[t]{2}{*}{ mobile } & $0.00617^{* * *}$ & 0.00392 & $0.00609^{* *}$ & $0.00446^{* *}$ & $0.00428^{*}$ \\
\hline & $(0.00214)$ & $(0.00235)$ & $(0.00274)$ & $(0.00197)$ & $(0.00215)$ \\
\hline \multirow[t]{2}{*}{ gdpg } & $0.0471^{* * *}$ & 0.0274 & 0.0232 & 0.0273 & 0.0237 \\
\hline & $(0.0162)$ & $(0.0238)$ & $(0.0211)$ & $(0.0205)$ & (0.0198) \\
\hline \multirow[t]{2}{*}{ fdind } & $2.504^{* * *}$ & $2.795^{* * *}$ & $2.038^{* * *}$ & $2.639^{* * *}$ & $1.854^{* * * *}$ \\
\hline & $(0.358)$ & $(0.676)$ & $(0.459)$ & $(0.432)$ & $(0.587)$ \\
\hline \multirow[t]{2}{*}{ patenta } & $0.112^{*}$ & $0.209^{* * *}$ & $0.112^{*}$ & 0.121 & $0.152^{* *}$ \\
\hline & $(0.0539)$ & $(0.0648)$ & $(0.0585)$ & $(0.0782)$ & $(0.0555)$ \\
\hline \multirow[t]{2}{*}{ corruption } & & 0.111 & & & \\
\hline & & $(0.0919)$ & & & \\
\hline \multirow[t]{2}{*}{ law } & & & 0.0150 & & \\
\hline & & & $(0.0336)$ & & \\
\hline \multirow[t]{2}{*}{ bur } & & & & -0.0503 & \\
\hline & & & & $(0.0579)$ & \\
\hline \multirow[t]{2}{*}{ milt } & & & & & $0.0642^{*}$ \\
\hline & & & & & $(0.0346)$ \\
\hline \multirow[t]{2}{*}{ Constant } & $-1.482^{* * *}$ & $-2.598^{* * *}$ & $-2.180^{* * *}$ & $-1.923^{* * *}$ & $-2.627^{* * *}$ \\
\hline & $(0.446)$ & $(0.673)$ & $(0.430)$ & $(0.477)$ & $(0.502)$ \\
\hline Observations & 479 & 354 & 405 & 421 & 432 \\
\hline R-squared & 0.714 & 0.663 & 0.643 & 0.657 & 0.645 \\
\hline Number of year & 22 & 22 & 22 & 22 & 22 \\
\hline Country FE & YES & YES & YES & YES & YES \\
\hline Year FE & YES & YES & YES & YES & YES \\
\hline
\end{tabular}

Robust standard errors in parentheses

${ }^{* * *} p<0.01,{ }^{* *} p<0.05,{ }^{*} p<0.1$

explanatory power of the model is 64

\section{Conclusion}

The study explained the impact of financial development, institutional quality and intellectual property right on foreign direct investment during 1980 to 2016 in sample of 123 countries finding in various income groups. Historically many theories such as imperfect market theories, industrial organizational theory internationalism theory imperfect market theories and institutional approach theory explained inflow of FDI that dealt with an attempt to link theory with trends of FDI along with information asymmetry with strategic de- cision making. In regard to above theories this study is based on OLI theory proposed by Dunning 1980 or eclectic or ownership ,location and internationalism theory. Very few researchers have attempted to study the relationship between inflow of foreign direct investment as a dependent variable and OLI paradigm independently for the developing economies. However, this is considered an important theory as a base of the study because it is related to foreign direct investment.

Though FDI is recurrently examined on diverse disciplines such as international economics, geographical economics, worldwide business and management, none of the theory can completely explain the phenomena of FDI. Thus, complete analysis of FDI from empirical and theoretical perspectives indispensably ex- 
plains institutional quality level of financial development. The study reveals that two proxies of institutional quality i.e. bureaucracy and military in general influence performance of institutional quality of FDI. The study explains that the model is $70 \%$ when financial development is added to the macro economic variables.

Strong Bureaucratic rule of law will lower the foreign direct investment. As investors are less likely to be fascinated to such nations where there are stringent policies. Investors are more likely where there is adjusting and flexible law. Similarly patenta is the proxy to measure the intellectual property right it means protection of IPR and its strengthening process will ultimately harmonize the economy. Size of the economy has significant impact on FDI. Macro-economic variables such as size of economy will affect FDI. Big economies will attract more FDI. Similarly Labor force and FDI have significant relationship with FDI. The countries that have cheap labor manpower will attract more FDI. Trade openness has significant relationship with FDI. This means more open trade policies will appeal extra foreign direct investment (FDI). Inflation is partially significant, so low level of inflation will influence FDI. Mobile phone per 100 people is significant as there exists more technology usage by masses Financial development index is used as a proxy of financial development. Sound and well developed financial institution enhances more financial development. This would enhance more FDI inflow. Financial development index is significant financial market index is used as a proxy of financial development .sound and well established market enhance more financial development. This would ultimately increase more FDI inflow. Financial market index is significant.

The study has strong policy implications .Intellectual property right and patent protection and its strengthening will harmonize the country and facilitate the FDI and attracted the foreign investors as well. It will also help in the promotion of the technology innovation and creativity to the extent to the transferring and dissemination of the technology. Developed countries where there are TRIPs agreements are followed will ultimately enhance the foreign direct investment thus the monopolistic nature of the IPR will affect the foreign direct investment.

Results of study indicate that size of economy can be boosted by reducing corruption and in general via improving role of institutional quality. For reducing the reliance on external finance developing countries should concentrate on improving the level of capital formation at home. Study has some policy implications for developing countries; governments of developing countries should take necessary actions for making institutions strong primarily regulatory quality in particular strong accountability.

\section{References}

Adams, S. (2008). Globalization and income inequality: Implications for intellectual property rights. Journal of Policy Modeling, 30(5):725-735.

Agbloyor, E. K., Abor, J., Adjasi, C. K. D., and Yawson, A. (2013). Exploring the causality links between financial markets and foreign direct investment in africa. Research in International Business and Finance, 28:118-134.

Aharoni, Y. (2010). Behavioral elements in foreign direct investments. In The Past, Present and Future of International Business \& Management, pages 73-111. Emerald Group Publishing Limited.

Bénassy-Quéré, A., Coupet, M., and Mayer, T. (2007). Institutional determinants of foreign direct investment. World economy, 30(5):764-782.

Bevan, A., Estrin, S., and Meyer, K. (2004). Foreign investment location and institutional development in transition economies. International business review, 13(1):43-64.

Buchanan, B. G., Le, Q. V., and Rishi, M. (2012). Foreign direct investment and institutional quality: Some empirical evidence. International Review of financial analysis, 21:81-89.

Busse, M. and Hefeker, C. (2007). Political risk, institutions and foreign direct investment. European journal of political economy, 23(2):397-415.

Cheung, K.-y. and Ping, L. (2004). Spillover effects of fdi on innovation in china: Evidence from the provincial data. China economic review, 15(1):25-44.

Cuervo-Cazurra, A. (2006). Who cares about corruption? Journal of international business studies, 37(6):807-822.

Dunning, J. H. and Zhang, F. (2008). Foreign direct investment and the locational competitiveness of countries. Transnational corporations, 17(3):1.

Fellner, G. and Maciejovsky, B. (2007). Risk attitude and market behavior: Evidence from experimental asset markets. Journal of Economic Psychology, 28(3):338-350.

Fischer, R. D. (2001). The evolution of inequality after trade liberalization. Journal of Development Economics, 66(2):555579.

Gani, A. (2007). Governance and foreign direct investment links: evidence from panel data estimations. Applied economics letters, 14(10):753-756.

Gervais, D. J. (2005). Intellectual property, trade \& (and) development: The state of play. Fordham L. Rev., 74:505.

Glass, A. J. (1997). Product cycles and market penetration. International Economic Review, pages 865-891.

Grossman, G. M. and Lai, E. L.-C. (2004). International protection of intellectual property. American Economic Review, 94(5):1635-1653. 
Henriques, R., Lelek, M., Fornasiero, E. F., Valtorta, F., Zimmer, C., and Mhlanga, M. M. (2010). Quickpalm: 3d realtime photoactivation nanoscopy image processing in imagej. Nature methods, 7(5):339.

Hermes, N. and Lensink, R. (2003). Foreign direct investment, financial development and economic growth. The Journal of Development Studies, 40(1):142-163.

Iwaisako, T. (2018). Welfare effects of patent protection in a semi-endogenous growth model. Macroeconomic Dynamics, pages 1-21.

Jahn, B. (2009). Liberal internationalism: from ideology to empirical theory-and back again. International Theory, 1(3):409-438.

Kaufmann, D. and Wei, S.-J. (1999). Does" grease money" speed up the wheels of commerce? Technical report, National bureau of economic research.

Kinda, T. (2010). Investment climate and fdi in developing countries: firm-level evidence. World development, 38(4):498-513.

Maskus, K. E., Saggi, K., and Puttitanun, T. (2005). Patent rights and international technology transfer through direct investment and licensing. International Public Goods and the Transfer of Technology under a Globalized Intellectual Property Regime, pages 265-281.

Moosa, I. A. and Cardak, B. A. (2006). The determinants of foreign direct investment: An extreme bounds analysis. Journal of Multinational Financial Management, 16(2):199211.

Naik, R., Singh, D. P., and Chaudhary, J. (2018). A survey on comparative analysis of different ica based face recognition technologies. In 2018 Second International Conference on Electronics, Communication and Aerospace Technology (ICECA), pages 1913-1918. IEEE.

North, D. (1997). Instituty, institutsionalnyye izmeneniya i funktsionirovaniye ekonomiki [institutions, institutional change and economic performance]. Moscow: Fond ekonomicheskikh knig Nachala(in Russian).

Park, W. G. and Ginarte, J. C. (1997). Intellectual property rights and economic growth. Contemporary Economic Policy, 15(3):51-61.
Pichler, P. and Wilhelm, W. (2001). A theory of the syndicate: Form follows function. The Journal of Finance, 56(6):22372264.

Puerta-Gomez, A. F. and Cisneros-Zevallos, L. (2011). Postharvest studies beyond fresh market eating quality: Phytochemical antioxidant changes in peach and plum fruit during ripening and advanced senescence. Postharvest Biology and Technology, 60(3):220-224.

Santiso, C. (2001). Good governance and aid effectiveness: The world bank and conditionality. The Georgetown public policy review, 7(1):1-22.

Schneider, P. H. (2005). International trade, economic growth and intellectual property rights: A panel data study of developed and developing countries. Journal of Development Economics, 78(2):529-547.

Singh, A. (2003). Capital account liberalization, free longterm capital flows, financial crises and economic development. Eastern Economic Journal, 29(2):191-216.

Smarzynska Javorcik, B. (2004). Does foreign direct investment increase the productivity of domestic firms? in search of spillovers through backward linkages. American economic review, 94(3):605-627.

Stanley, M. H., Amaral, L. A., Buldyrev, S. V., Havlin, S., Leschhorn, H., Maass, P., Salinger, M. A., and Stanley, H. E. (1996). Scaling behaviour in the growth of companies. $\mathrm{Na}$ ture, 379(6568):804.

Strine Jr, L. E. (2010). One fundamental corporate governance question we face: Can corporations be managed for the long term unless their powerful electorates also act and think long term. Bus. Law., 66:1.

Wooldridge, J. M. (2015). Introductory econometrics: A modern approach. Nelson Education.

Xavier-Oliveira, E., Laplume, A. O., and Pathak, S. (2015). What motivates entrepreneurial entry under economic inequality? the role of human and financial capital. Human Relations, 68(7):1183-1207. 